\title{
RESEARCH
}

Open Access

\section{Predisposing, enabling, and need factors associated with utilization of HCV testing services among PWID in two settings in India}

Ruchi Sogarwal", Varada Madge, Pratyush Bishi, Apam Woleng and Rishi Garg

\begin{abstract}
Background: The Hepatitis C virus (HCV) is very common among people who inject drugs (PWID), yet PWID in India have suboptimal access to HCV testing and treatment. This study sought to identify HCV risk factors among male PWID who utilized a free needle and syringe exchange program and to examine the predisposing, enabling, and need factors associated with utilization of HCV testing services by those PWID reporting that they had been tested.

Methods: A cross-sectional study was conducted in Imphal, Manipur and Amritsar, Punjab. These two settings have high HCV prevalence and large numbers of PWID. A team of 18 field investigators obtained data through face-to-face interviews using a structured multiple-choice questionnaire. The questionnaire was administered to 1241 of 2644 male PWID aged 15 years and above enrolled in the needle and syringe program of India's AIDS Control Program, with study participants selected through consecutive sampling. Statistical analyses included descriptive statistics and multivariate regression.

Results: Twenty-four percent of PWID in our study sample reported having been tested for HCV. Unlike PWID in Imphal, more than half of PWID in Amritsar reported unprotected sex and use of alcohol or non-injecting drugs as being among their HCV risk factors (67.1 and $77.8 \%$, respectively). However, opioid substitution therapy non-adherence was reported more often in Imphal than in Amritsar. Education, marital status, place of residence and duration of injecting drug use were found to significantly enable access to HCV testing while alcohol use, frequent mobility and unprotected sex were found to significantly inhibit access to HCV testing for PWID after controlling for other explanatory variables.

Conclusions: Predisposing and enabling determinants provide an area for developing effective interventions to improve HCV testing practices among PWID. HCV prevention programs that address safe injecting and sexual practices, OST adherence and frequent mobility customized for PWID by age are strongly recommended.
\end{abstract}

Keywords: Hepatitis C virus, People who inject drugs, India

*Correspondence: ruchi.dr@gmail.com; ruchis@mamtahimc.org

MAMTA Health Institute for Mother and Child, New Delhi, India 


\section{Background}

Hepatitis $\mathrm{C}$ virus (HCV) is a global public health problem, with around 150 million people chronically infected [1]. Approximately $2.7 \%$ of all deaths annually are thought to be attributable to $\mathrm{HCV}$ [2]. This translates into one million deaths, most resulting from $\mathrm{HCV}$-associated cirrhosis or HCV-associated liver cancer [3-5]. People who inject drugs (PWID) have disproportionately high $\mathrm{HCV}$ prevalence worldwide (50-90 \%) in comparison to the general population [6]. Indian studies have reported HCV sero-positivity in PWID to be between 20 and $90 \%$. Some Indian PWID populations have extremely high HCV seroprevalence, while others have $\mathrm{HCV}$ seroprevalence in the more moderate range of 30 to $50 \%$ [7-10]. Despite the high burden of disease in Indian PWID, the problem has not been addressed in a systematic way. Recently, national initiatives to increase case finding have been proposed, including recommendations for improved laboratory-based surveillance [11]. These initiatives are timely since recent treatment advances have resulted in most cases of chronic $\mathrm{HCV}$ being curable with the use of direct-acting antiviral regimens [12-14]. The prospects of translating these advances into population-level declines in $\mathrm{HCV}$ disease are currently limited by the fact that 50 to $75 \%$ of HCVinfected individuals are unaware of their sero-status. Those under age 30 are particularly likely to be undiagnosed or to have experienced a late diagnosis [15-17].

In light of overlapping risk factors for transmission of viral hepatitis and HIV infection, as well as limited public health resources in many settings, the World Health Organization along with other experts has recommended integrating HCV and HIV services [18, 19]. In 2014, with the support of the Bristol-Myers Squibb Foundation [20], MAMTA Health Institute for Mother and Child [21] launched an initiative to reduce transmission of $\mathrm{HCV}$ and to improve patient care by integrating viral hepatitis prevention into existing public health programs providing HIV-related services to PWID in two settings in India: Amritsar District, in the state of Punjab, and Imphal District, in the state of Manipur. Historically, injection drug use was concentrated in the northeastern part of India, including Manipur, but rapidly growing populations of injection drug users have been reported in Punjab [22, 23]. Estimated HCV prevalence among PWID is $64.9 \%$ in Imphal and $48.7 \%$ in Amritsar [7].

The MAMTA intervention sought to empower people to seek health services early in regard to HCV screening, diagnosis and treatment, as well as to build the capacity of frontline health workers. It used the existing HIV program as a pathway for the expansion of viral hepatitis services, including vaccination, screening, confirmatory testing, and referral to care and treatment. In the first phase of the intervention, testing PWID for HCV was regarded as a key strategy and also an opportunity to promote health services and risk reduction services. However, program planners were hampered by a lack of knowledge about the characteristics of the population being targeted.

This study addresses the need for information in two ways. First, it investigates $\mathrm{HCV}$ risk factors among PWID utilizing a free needle and syringe exchange program. Second, it investigates which predisposing, enabling, and need factors were associated with utilization of HCV testing services by PWID. The conceptual framework for the study is based on the Gelberg-Andersen Behavioral Model for Vulnerable Populations [24], which has been extensively applied to the study of HIV testing in high-risk individuals [25-28]. Predisposing factors are demographic and other personal characteristics that influence the likelihood of obtaining care. Enabling factors are personal, family and community resources that support or encourage efforts to access health services. Need factors arise from the real or perceived need for health services and provide motivation for individuals to seek those services. In the absence of any similar research on HCV testing, we utilised the HIV literature to develop the hypothesis that are tested in this study. The hypothesis is that the predisposing factors would be associated with lower odds of utilisation of $\mathrm{HCV}$ testing as compared to enabling and need factors.

By comparing risk factors and $\mathrm{HCV}$ testing behavior in two settings that vary in regard to the nature of their drug use epidemics and HCV epidemics, this study also presents an opportunity to investigate whether different areas of India may benefit from different HCV prevention and testing approaches.

\section{Methods}

\section{Study setting and participants}

We surveyed male PWID utilizing a free multi-site needle and syringe exchange program in the districts of Amritsar and Imphal. Needle and syringe exchange took place at the community organization facilities of the Indian government's State AIDS Control Program [29]. Facilities were selected to participate in the study if they met three criteria: willingness of facility managers; available financial resources; and more than 200 PWID enrolled for services. These criteria resulted in one out of nine facilities in Amritsar serving as a study site, along with five out of 23 facilities in Imphal. Consecutive individuals who were at least 15 years old and reported a history of injecting drug use were invited to participate in the study when they attended the needle and syringe exchange facilities at these six sites from April 2015 through July 2015.

\section{Instrument and variables}

The data were obtained through face-to-face interviews by a team of 18 field investigators using a structured 
multiple-choice questionnaire that addressed prominent risk factors for $\mathrm{HCV}$ infection. The questionnaire included five domains relating to socio-demographic characteristics of the respondents, injecting patterns and practices, sexual practices, and other risk behaviors related to $\mathrm{HCV}$ including information about spouses and parents. The questionnaire was developed in English then translated into Hindi and Manipuri. All study participants were interviewed in the primary local language (Hindi in Amritsar and Manipuri in Imphal).

The main variable of interest (dependent variable) was self-report of ever receiving HCV testing. For the analysis of this study, we categorized independent variables into predisposing, enabling, and need factors in accordance with the previously described Gelberg-Andersen Behavioral Model for Vulnerable Populations [24]. Predisposing factors included age, education level, marital status, and use of alcohol and/or non-injecting drugs in the previous 1 month. Variables categorized as enabling factors included income status, 'below-poverty-line' status, level of mobility, district of residence, tattoo/piercing, unprotected sex in last 1 month, and sex with female sex workers in the last 1 month. Study participants were classified as belonging to either belowpoverty-line (BPL) households or non-BPL households as defined by the government of India on the basis of three categories of vulnerability: residential, occupational and social [30]. Study participants were considered to be highly mobile if they spent more than 10 days per month interacting with other PWID at locations outside of the community where they resided [31]. The variables included as need factors were $\mathrm{HCV}$-positive status of spouse or either parent; ever had transfusion of blood or blood components; ever had medical/dental surgery or hemodialysis; ever had needle stick injury; and sexually transmitted infection symptoms or treatment reported in last 1 month. Since frequency of injecting drug use is associated with likelihood of HCV transmission [32, 33], we included variables measuring current injecting drug use, injecting in groups in last 1 month, sharing needles/ syringes and other equipment in last 1 month, and duration of injecting drug use.

\section{Statistical analysis}

Descriptive analyses were used to assess the characteristics of study participants and the occurrence of $\mathrm{HCV}$ risk factors among younger PWID (aged 15-29) and older PWID (aged 30-44). In order to understand differentials in level of HCV risk factors by age and district of residence, ratios were computed. A ratio value of less than 1 would mean that the levels of risk factors were relatively higher for clients in the reference category compared to other clients, and a ratio value of more than 1 would mean the opposite, while a value of 1 would indicate no difference in the risk factors by age (reference category: $<30$ years) or district of residence (reference category: Amritsar). Bivariate analysis examined associations between the dependent variable and predisposing, enabling, and need factors. All variables that were significantly associated with the dependent variable were included in multivariate regression modeling. All $p$-values less than 0.05 were considered significant. Results are presented as odds ratios (ORs), with the relationship between exposure (independent variable) and an outcome (i.e. HCV testing) compared to no exposure. We reported higher odds $(\mathrm{OR}>1)$ when this relationship is positive, and lower odds $(\mathrm{OR}<1)$ when the relationship is negative. All statistical analyses were performed using SPSS 21.0 (IBM Corp, Armonk NY, 2012).

\section{Results}

Among 2644 needle and syringe exchange users invited to participate in the study, 1241 agreed (46.9 \%). Two hundred and eighty eight of the 1241 study respondents were HIV positive. The overall mean age of study participants was 33.4 years. Imphal had a much larger proportion of study participants aged 30 and above (81.2\%) than did Amritsar (37.3 \%) (Table 1). Less than $10 \%$ of study participants had no formal education, and most reported completing either primary education (22.0\%) or secondary education (55.9\%). Just over half of study participants reported currently being married, while $42.3 \%$ had never been married. More than four-fifths of people were employed, including those who reported part-time employment and self-employment. More than three-quarters had a monthly income of 6000 Indian Rupees (INR) or less (38.3 \%, <3000 INR; 41.9 \%, 30016000 INR), and approximately one-third met the criteria for below-poverty-line status. Study participants in Amritsar had engaged in injecting drug use for a median of 3.0 years, while those in Imphal had engaged in injecting drug use for a median of 8.6 years.

\section{Self-reported HCV risk factors}

Findings for self-reported HCV risk factors were disaggregated by both place of residence (Amritsar versus Imphal) and age ( $<30$ years versus $\geq 30$ years) (Table 2 ).

The Amritsar study cohort had more people under age 30 than age 30-plus who reported injecting daily in the last 1 month (11.6 versus $6.4 \%$; ratio: 0.6 ). The inverse relationship was seen in Imphal, where $28.7 \%$ of people under age 30 and $34.4 \%$ of people age 30-plus reported injecting daily in the last 1 month (ratio: 1.2). A similar pattern was seen for non-adherence to opioid substitution therapy. More Amritsar study participants under age 30 than age 30-plus reported non-adherence (22.5 versus $15.8 \%$; ratio: 0.7), while more Imphal study participants age 30 -plus reported non-adherence (60.0\%) 
Table 1 Sociodemographic characteristics of PWID in Amritsar and Imphal districts, India

\begin{tabular}{llll}
\hline Characteristics & Amritsar & Imphal & Total \\
& $(N=507)$ & $(N=734)$ & $(N=1241)$ \\
& $N(\%)$ & $N(\%)$ & $N(\%)$
\end{tabular}

Age (years)

$\begin{array}{llll}15-19 & 15(3.0) & 11(1.5) & 26(2.1) \\ 20-29 & 303(59.8) & 127(17.3) & 430(34.6) \\ \geq 30 & 189(37.3) & 596(81.2) & 785(63.3)\end{array}$

Education

\begin{tabular}{|c|c|c|c|}
\hline No formal education & $65(12.8)$ & $50(6.8)$ & $115(9.3)$ \\
\hline $\begin{array}{l}\text { Primary (up to } 5 \text { years } \\
\text { of schooling) }\end{array}$ & $174(34.3)$ & 99 (13.5) & $273(22.0)$ \\
\hline $\begin{array}{l}\text { Secondary (up to } 10 \text { years } \\
\text { of schooling) }\end{array}$ & $249(49.1)$ & $445(60.6)$ & $694(55.9)$ \\
\hline $\begin{array}{l}\text { Higher (up to } 12 \text { years of } \\
\text { schooling or beyond) }\end{array}$ & $19(3.7)$ & $140(19.1)$ & $159(12.8)$ \\
\hline \multicolumn{4}{|l|}{ Marital status } \\
\hline Currently married & $232(45.8)$ & $404(55.0)$ & $636(51.2)$ \\
\hline $\begin{array}{l}\text { Widowed, divorced } \\
\text { or separated }\end{array}$ & $19(3.7)$ & $61(8.3)$ & $80(6.4)$ \\
\hline Never married & $256(50.5)$ & $269(36.6)$ & $525(42.3)$ \\
\hline \multicolumn{4}{|l|}{ Employment status } \\
\hline $\begin{array}{l}\text { Employed (including } \\
\text { part-time employment } \\
\text { and self-employment) }\end{array}$ & $393(77.5)$ & $625(85.1)$ & $1018(82.0)$ \\
\hline Not employed & $114(22.5)$ & 109 (14.9) & $223(18.0)$ \\
\hline
\end{tabular}

Monthly income (Indian Rupees)

$\begin{array}{llll}\leq 3000 & 122(24.1) & 353(48.1) & 475(38.3) \\ 3001-6000 & 270(53.3) & 250(34.1) & 520(41.9) \\ 6001-10,000 & 75(14.8) & 55(7.5) & 130(10.5) \\ >10,001 & 40(7.9) & 76(10.4) & 116(9.3)\end{array}$

Below-poverty-level (BPL) status ${ }^{a}$

$\begin{array}{llll}\text { Not below poverty level } & 383(75.5) & 438(59.7) & 821(66.2) \\ \text { Below poverty level } & 124(24.5) & 296(40.3) & 420(33.8)\end{array}$

Age at sexual debut (years)

$\begin{array}{llll}\text { Mean } \pm \text { SD } & 18.0 \pm 2.8 & 23.7 \pm 5.7 & 21.2 \pm 5.5 \\ \text { Median (range) } & 18.0(10-31) & 24.0(10-48) & 20.0(10-48)\end{array}$

Duration of injecting

drug use (years)

$\begin{array}{llll}\leq 1 & 130(25.6) & 42(5.7) & 172(13.9) \\ 2-5 & 292(57.6) & 137(18.7) & 429(34.6) \\ 6-10 & 49(9.7) & 190(25.9) & 239(19.3) \\ \geq 11 & 36(7.1) & 365(49.7) & 401(32.3) \\ \text { Mean } \pm \text { SD } & \pm 4.4 & 13.3 \pm 11.0 & 9.5 \pm 8.5 \\ \text { Median (range) } & 3.0(1-35) & 8.6(1-35) & 7(1-35)\end{array}$

${ }^{a} \mathrm{BPL}$ status was determined in accordance with the definition used by the Indian government (Planning Commission, Government of India: Report of the expert group to review the methodology for measurement of poverty; June 2014; http://planningcommission.nic.in/reports/genrep/pov rep0707.pdf) in comparison to the under-30 Imphal cohort (53.8 \%) (ratio: 1.1)

In both Amritsar and Imphal, there was more reported sharing of injecting equipment in the last 1 month among under-30 study participants than among those age 30-plus, although the difference was greater in Amritsar (24.6 versus $16.9 \%$; ratio: 0.7). Similarly, larger proportions of under-30 study participants in both locations reported "ever had tattoo or piercing" as a risk factor. Regarding a third HCV risk factor, unprotected sex in the last 1 month, both locations had larger proportions of older study participants than younger study participants reporting that they had engaged in this behavior (Amritsar: <30 years, $67.1 \%$; $\geq 30$ years, $78.4 \%$; ratio: 1.2; Imphal: $<30$ years, $29.5 \%$; $\geq 30$ years, $51.8 \%$; ratio: 1.8$)$.

When study participants under age 30 in Imphal were compared to study participants under age 30 in Amritsar, various differences were observed. A much larger proportion of the Imphal cohort than the Amritsar cohort reported injecting daily in the last month (28.7 versus $11.6 \%$; ratio: 2.5 ). On the other hand, smaller proportions of younger study participants in Imphal than in Amritsar reported other risk factors such as sharing of injecting equipment in the last 1 month (13.4 versus $24.6 \%$; ratio: 0.5 ), unprotected sex in the last month (29.5 versus $67.1 \%$; ratio: 0.4 ), and ever had tattoo or piercing (26.7 versus $32.7 \%$; ratio: 0.8 ). Regarding OST non-adherence in the last 1 month, $22.5 \%$ of study participants under age 30 in Amritsar reported nonadherence, while $53.8 \%$ of those under age 30 in Imphal did so (ratio: 2.4).

The age 30-plus study cohort had a similar pattern in risk factors across the two locations. A much larger proportion of older Imphal study participants reported being daily injectors in the last month in comparison to their counterparts in Amritsar (34.4 versus 6.4 \%; ratio: 5.4). A much smaller proportion of older Amritsar study participants reported OST non-adherence in the last 1 month in comparison to the older Imphal cohort (15.8 versus $60.0 \%$; ratio: 3.8 ). Several other risk factors were reported by larger proportions of age 30-plus Amritsar residents than age 30-plus Imphal residents, including sharing of injecting equipment in the last 1 month (16.9 versus $12.0 \%$; ratio: 0.7 ); unprotected sex in the last 1 month (78.4 versus $51.8 \%$; ratio: 0.7 ); and ever had tattoo or piercing ( 24.5 versus $12.4 \%$; ratio: 0.5 ).

\section{Factors associated with utilization of HCV testing}

Two hundred and ninety-eight of the 1241 study participants $(24.0 \%)$ reported that they had been tested for HCV.

Three of four predisposing factors were significantly associated with HCV testing (Table 3). Study participants with any formal education were more likely to 
Table 2 HCV risk factors reported by younger (<30 years) and older ( $\geq 30$ years) study participants, by place of residence $(N=1241)$

\begin{tabular}{|c|c|c|c|c|c|c|c|c|}
\hline \multirow[t]{3}{*}{ Reported HCV risk } & \multicolumn{2}{|c|}{ Amritsar $(N=507)$} & \multicolumn{2}{|c|}{ Imphal $(N=734)$} & \multicolumn{2}{|c|}{$\begin{array}{l}\text { Ratio } \\
\text { ( } \geq 30 \text { years/ } \\
<30 \text { years) }\end{array}$} & \multicolumn{2}{|c|}{ Ratio (IMP/AMR) } \\
\hline & $<30$ years & $\geq 30$ years & $<30$ years & $\geq 30$ years & AMR & IMP & $<30$ years & $\geq 30$ years \\
\hline & $(n=318)$ & $(n=189)$ & $(n=138)$ & $(n=596)$ & & & & \\
\hline Daily injector in last 1 month & $36 / 311(11.6)$ & $12 / 188(6.4)$ & $37 / 129(28.7)$ & $178 / 518(34.4)$ & 0.6 & 1.2 & 2.5 & 5.4 \\
\hline $\begin{array}{l}\text { More than } 30 \text { injecting episodes per } \\
\text { month in last consecutive } 3 \text { months }\end{array}$ & 24/153 (15.7) & 10/73 (13.7) & $46 / 104(44.2)$ & $177 / 369(47.9)$ & 0.9 & 1.1 & 3.2 & 3.4 \\
\hline Injecting in a group in last 1 month & $134 / 314(42.7)$ & $57 / 188(30.3)$ & $55 / 126(43.7)$ & $153 / 502(30.5)$ & 0.7 & 0.7 & 1.0 & 1.0 \\
\hline $\begin{array}{l}\text { Sharing of needles/ syringes and other } \\
\text { equipment in last } 1 \text { month }\end{array}$ & 77/313 (24.6) & $32 / 189(16.9)$ & $17 / 126(13.4)$ & $62 / 516(12.0)$ & 0.7 & 0.9 & 0.5 & 0.7 \\
\hline Unprotected sex in last 1 month & 186/277 (67.1) & 131/167 (78.4) & $38 / 129(29.5)$ & 275/531 (51.8) & 1.2 & 1.8 & 0.4 & 0.7 \\
\hline Sex with female sex worker in last 1 month & $42 / 314(13.4)$ & 13/188 (6.9) & $4 / 133(3.0)$ & $11 / 578(1.9)$ & 0.5 & 0.6 & 0.2 & 0.3 \\
\hline STI symptoms or STI treatment in last 1 month & 10/315 (3.2) & $3 / 189(1.6)$ & $1 / 132(0.8)$ & $4 / 571(0.7)$ & 0.5 & 0.8 & 0.2 & 0.4 \\
\hline $\begin{array}{l}\text { Use of alcohol and/or other non-injecting } \\
\text { drugs in last } 1 \text { month }\end{array}$ & 245/315 (77.8) & $177 / 189(77.8)$ & 77/133 (57.9) & $284 / 579(49.1)$ & 1.0 & 0.8 & 0.7 & 0.6 \\
\hline $\begin{array}{l}\text { Opioid substitution therapy non-adherence } \\
\text { in last } 1 \text { month }\end{array}$ & $71 / 315(22.5)$ & $30 / 189(15.8)$ & 71/132 (53.8) & $348 / 580(60.0)$ & 0.7 & 1.1 & 2.4 & 3.8 \\
\hline High mobility in last 1 month ${ }^{a}$ & $26 / 307(8.5)$ & 10/187 (5.3) & 28/132 (21.2) & 110/577 (19.1) & 0.6 & 0.9 & 2.5 & 3.6 \\
\hline $\begin{array}{l}\text { Mother, father or spouse ever tested } \\
\text { HCV-positive }\end{array}$ & $1 / 314(0.3)$ & $0 / 189(0)$ & $3 / 131(2.3)$ & 18/572 (3.1) & 0.0 & 1.3 & 7.7 & - \\
\hline Ever had tattoo or piercing & $102 / 312(32.7)$ & $46 / 188(24.5)$ & $35 / 131(26.7)$ & 72/581 (12.4) & 0.7 & 0.5 & 0.8 & 0.5 \\
\hline $\begin{array}{l}\text { Ever had transfusion of blood or blood } \\
\text { components }\end{array}$ & $18 / 314(5.7)$ & 15/189 (7.9) & $1 / 132(0.8)$ & 18/579 (3.1) & 1.4 & 3.9 & 0.1 & 0.4 \\
\hline $\begin{array}{l}\text { Ever had medical or dental surgery, or } \\
\text { hemodialysis }\end{array}$ & 13/315 (4.1) & 25/189 (13.2) & 1/131 (0.8) & $16 / 582(2.7)$ & 3.2 & 3.4 & 0.2 & 0.2 \\
\hline Ever had needle stick injury & $0 / 315$ & $1 / 188(0.5)$ & $3 / 130(2.3)$ & 10/573 (1.7) & - & 0.7 & - & 3.4 \\
\hline
\end{tabular}

a High mobility for PWID is defined as spending more than 10 days per month interacting with other PWID at locations outside of the community where one resides

report testing than those with no formal education (adjusted odds ratio $[\mathrm{aOR}] 3.5,95 \%$ confidence interval [CI] 1.2-10.4, $p=0.022$ ). Currently married study participants were more likely to report testing than those who were not (aOR 2.4, CI 1.3-4.5, $p=0.004)$. Study participants who reported using alcohol and/or other noninjecting drugs in the last 1 month were less likely than those who did not to report testing (aOR 0.6, CI 0.4-0.9, $p=0.016$ ). As for the fourth predisposing factor, $9.7 \%$ of study participants under age 30 and $32.2 \%$ of study participants age 30 -plus reported testing, but the older age group did not have significantly higher odds of testing (aOR 1.4, CI 0.8-2.3, $p=0.208$ ).

Three of seven enabling factors were significantly associated with HCV testing. Residents of Imphal were much more likely than residents of Amritsar to report testing (aOR 4.9, CI 2.7-8.8, $p<0.001$ ). Study participants who reported using condoms in the last 1 month were less likely to report testing than those who did not (aOR 0.5, CI $0.3-0.9, p=0.015)$, as were those who reported high mobility in the last 1 month in comparison to those who did not (aOR 0.5, CI 0.3-0.8, $p=0.005$ ).
Among five need factors, only one was significantly associated with HCV testing. Study participants who had been injecting drugs for 11 or more years were more likely to report testing than those who had been injecting for 1 year or less (aOR 2.1, CI 1.0-4.2, $p=0.050$ ).

\section{Discussion}

This cross-sectional study investigated prevalence of HCV risk factors among 1241 male PWID utilizing a free needle and syringe exchange program in two distinct settings in India, as well as assessing which factors were associated with utilization of HCV testing services. Study participants in Imphal, which has had an injection drug epidemic for longer than Amritsar, reported a much longer median number of years of injection drug use than their Amritsar counterparts. When reported $\mathrm{HCV}$ risk factors were compared across the study sites with study participants disaggregated into two age groups, some risk factors appeared to be more prominent among Amritsar PWID and other risk factors appeared to be more prominent among Imphal PWID regardless of age. For example, higher proportions of 
Table 3 Univariate and multivariate logistic regression analyses of factors associated with previous HCV testing among PWID ( $N=1241$ unless otherwise noted)

\begin{tabular}{|c|c|c|c|c|c|}
\hline \multirow[t]{2}{*}{ Factors } & \multirow{2}{*}{$\begin{array}{l}\text { Tested for } \\
\text { HCV (\%) }\end{array}$} & \multicolumn{2}{|l|}{ Univariate } & \multicolumn{2}{|l|}{ Multivariate } \\
\hline & & OR $(95 \% \mathrm{Cl})$ & $P$-value & Adjusted OR (95\% Cl) & $P$-value \\
\hline \multicolumn{6}{|l|}{ Predisposing factor } \\
\hline \multicolumn{6}{|l|}{ Age (years) } \\
\hline$<30$ & $45 / 456(9.7)$ & 1 & $<0.001$ & 1 & 0.208 \\
\hline$\geq 30$ & $253 / 785(32.2)$ & $4.4(3.1-6.2)$ & & $1.4(0.8-2.3)$ & \\
\hline \multicolumn{6}{|l|}{ Education } \\
\hline No formal education & 13/115 (11.3) & 1 & 0.001 & 1 & 0.022 \\
\hline Formal education (any) & 285/1126 (25.4) & $2.7(1.5-4.8)$ & & $3.5(1.2-10.4)$ & \\
\hline \multicolumn{6}{|l|}{ Marital Status } \\
\hline Widowed, divorced, separated or never married & $112 / 605(18.5)$ & 1 & $<0.001$ & 1 & 0.004 \\
\hline Currently married & 186/636 (29.2) & $1.8(1.4-2.4)$ & & $2.4(1.3-4.5)$ & \\
\hline \multicolumn{6}{|l|}{$\begin{array}{l}\text { Use of alcohol and/or other non-injecting } \\
\text { drugs in last } 1 \text { month }(N=1186)\end{array}$} \\
\hline No & 162/433 (37.4) & 1 & $<0.001$ & 1 & 0.016 \\
\hline Yes & 129/753 (17.1) & $0.4(0.3-0.5)$ & & $0.6(0.4-0.9)$ & \\
\hline \multicolumn{6}{|l|}{ Enabling factor } \\
\hline \multicolumn{6}{|l|}{ District of residence } \\
\hline Amritsar & $28 / 507(5.5)$ & 1 & $<0.001$ & 1 & $<0.001$ \\
\hline Imphal & 270/734 (36.8) & $10.1(6.7-15.2)$ & & $4.9(2.7-8.8)$ & \\
\hline \multicolumn{6}{|l|}{ Employment status } \\
\hline Not employed & 263/1018 (25.8) & 1 & & 1 & 0.802 \\
\hline Employed & $35 / 223(15.7)$ & $0.5(0.4-0.8)$ & 0.002 & $1.1(0.6-1.8)$ & \\
\hline \multicolumn{6}{|l|}{ Below-poverty-level (BPL) status ${ }^{a}$} \\
\hline Not below poverty level & 157/821 (19.1) & 1 & $<0.001$ & 1 & 0.598 \\
\hline Below poverty level & $141 / 420(33.6)$ & $2.1(1.6-2.8)$ & & $1.1(0.8-1.6)$ & \\
\hline \multicolumn{6}{|l|}{ Unprotected sex in last 1 month $(N=1104)$} \\
\hline Always used condoms for sex & 131/474 (27.6) & 1 & 0.05 & 1 & 0.015 \\
\hline Did not always use condoms for sex & $143 / 630(22.7))$ & $0.8(0.6-1.0)$ & & $0.5(0.3-0.9)$ & \\
\hline \multicolumn{6}{|l|}{ High mobility in last 1 month $^{b}(N=1203)$} \\
\hline No & $253 / 1029(24.5)$ & 1 & 0.099 & 1 & 0.005 \\
\hline Yes & 33/174 (18.9) & $0.7(0.5-1.0)$ & & $0.5(0.3-0.8)$ & \\
\hline \multicolumn{6}{|l|}{$\begin{array}{l}\text { Sex with female sex worker in last } \\
1 \text { month }(N=1213)\end{array}$} \\
\hline No & $59 / 1143(5.2)$ & 1 & 0.106 & 1 & 0.195 \\
\hline Yes & $11 / 70(15.71)$ & $0.6(0.3-1.1)$ & & $2.1(0.7-6.8)$ & \\
\hline \multicolumn{6}{|l|}{ Ever had tattoo or piercing $(N=1212)$} \\
\hline No & 238/957 (24.8) & 1 & 0.083 & 1 & 0.259 \\
\hline Yes & 50/255 (19.6) & $0.7(0.5-1.0)$ & & $1.3(0.8-2.2)$ & \\
\hline \multicolumn{6}{|l|}{ Need factor } \\
\hline \multicolumn{6}{|l|}{$\begin{array}{l}\text { STI symptoms or STI treatment in last } \\
1 \text { month }(N=1207)\end{array}$} \\
\hline No & 280/1189 (23.5) & 1 & 0.345 & 1 & 0.170 \\
\hline Yes & 6/18 (33.3) & $1.6(0.6-4.3)$ & & $3.9(0.5-27.2)$ & \\
\hline
\end{tabular}

Current injecting drug user $(N=1211)$ 
Table 3 Univariate and multivariate logistic regression analyses of factors associated with previous HCV testing among PWID ( $N=1241$ unless otherwise noted) (Continued)

\begin{tabular}{|c|c|c|c|c|c|}
\hline No, but formerly & $131 / 512(25.6)$ & 1 & 0.163 & 1 & 0.525 \\
\hline Yes, currently (injected drugs in last 3 months) & $155 / 699(22.2)$ & $0.7(0.6-1.0)$ & & $0.9(0.6-1.3)$ & \\
\hline \multicolumn{6}{|l|}{ Injecting in a group in last 1 month $(N=1130)$} \\
\hline No & $171 / 731(23.4)$ & 1 & 0.009 & 1 & 0.619 \\
\hline Yes & $67 / 399(16.8)$ & $0.7(0.5-1.1)$ & & $1.1(0.7-1.8)$ & \\
\hline \multicolumn{6}{|l|}{$\begin{array}{l}\text { Sharing of needles/syringes and other } \\
\text { equipment in last } 1 \text { month }(N=1144)\end{array}$} \\
\hline No & $214 / 956(22.4)$ & 1 & & 1 & 0.365 \\
\hline Yes & $34 / 188(18.1)$ & $0.7(0.5-1.1)$ & 0.179 & $1.3(0.7-2.1)$ & \\
\hline \multicolumn{6}{|l|}{ Duration of injecting drug use (years) } \\
\hline$\leq 1$ & $21 / 172(12.2)$ & 1 & & 1 & 0.021 \\
\hline $2-5$ & $46 / 429(10.7)$ & $0.8(0.5-1.5)$ & 0.585 & $0.9(0.5-1.9)$ & 0.861 \\
\hline $6-10$ & $60 / 239(25.1)$ & $2.4(1.4-4.1)$ & 0.001 & $1.3(0.6-2.7)$ & 0.491 \\
\hline$\geq 11$ & $171 / 401$ (42.6) & $5.4(3.3-8.9)$ & $<0.001$ & $2.1(1.0-4.2)$ & 0.050 \\
\hline
\end{tabular}

${ }^{\mathrm{a} B P L}$ status was determined in accordance with the definition used by the Indian government (Planning Commission, Government of India: Report of the expert group to review the methodology for measurement of poverty. June 2014; http://planningcommission.nic.in/reports/genrep/pov_rep0707.pdf)

${ }^{b}$ High mobility for PWID is defined as spending more than 10 days per month interacting with other PWID at locations outside of the community where one resides

Amristar PWID in both age groups reported sharing needles/syringes and other injecting equipment in the last month, while higher proportions of Imphal PWID in both age groups experiencing OST non-adherence in the last month. Some risk factors also followed a consistent pattern across the two cities in relation to age. For example, higher proportions of PWID under age 30 in both cities reported injecting in groups in the last 1 month. At the same time, the two age groups exhibited different patterns of risk in different locations in certain regards. For example, more Amritsar PWID under age 30 had non-adherence to OST in the last month in comparison to older PWID in the same location, while older Imphal PWID reported this risk factor more often than did younger Imphal PWID. Among the subgroup of 298 study participants who reported previous HCV testing, Imphal residents were far more likely to do so than Amritsar residents, while age on the other hand was determined to not be a significant predictor of previous testing.

This study, by separately examining the potential influence of age and place of residence on PWID in relation to $\mathrm{HCV}$ risk, has provided evidence that some $\mathrm{HCV}$ related needs vary considerably across different Indian PWID subpopulations. One factor that may help to account for this variation is the longevity of the injecting drug use epidemic. Two HCV risk factors reported by higher proportions of Amritsar residents than Imphal residents were sharing injection equipment and having unprotected sex. We speculate that Amritsar with its newer injection drug epidemic may lag behind Imphal in regard to the provision of a range of services for PWID, including interventions to reduce the sharing of injection equipment and promote condom use. At the same time, PWID in a setting with a longtime drug use epidemic, such as Imphal, may also have specific unmet needs. In our study, both younger and older PWID in Imphal, unlike their counterparts in Amritsar, reported quite high levels of non-adherence to opioid substitution therapy. Since the provision of OST is regarded as a key component of a comprehensive approach to reducing $\mathrm{HCV}$ transmission and preventing $\mathrm{HCV}$ reinfection among PWID, our study finding points to a problem that should be addressed through geographically targeted interventions. Furthermore, the finding that OST non-adherence was somewhat higher among older Imphal PWID (60.0 \%) compared to younger Imphal PWID $(53.8 \%)$ suggests that age-targeted interventions addressing this issue might be beneficial in Imphal as well. One of the examples of the age-targeted intervention is the UFO (U Find Out) model for HCV prevention, a youth centered, collaborative and harm reduction based intervention, in which young IDU centered referral services are provided for early screening of HCV [34].

One-fourth of the PWID in our study reported ever being tested for $\mathrm{HCV}$. In multivariate analysis, Imphal residents were almost five times as likely as Amritsar residents to report previous HCV testing. Nonetheless, when $\mathrm{HCV}$ testing findings were disaggregated by place of residence, the reported HCV testing level among Imphal residents was still only $36.8 \%$. Numerous factors may account for this disparity, such as diversity in drug use, epidemic stage of $\mathrm{HCV}$ and socio-demographic and risk behaviours $[7,8]$. Additionally, prevention services 
such as the needle and syringe exchange are more numerous and accessible to Imphal residents; and PWID in this area may therefore have greater knowledge of available resources. There may be unmet needs for outreach services and a paucity of trained health care providers for PWID in less epidemic area. These results illustrate the need for expanded access to primary health care and prevention services that could be an important strategy to address an unmet need for individuals at high risk for $\mathrm{HCV}$ or detecting previously undiagnosed cases of $\mathrm{HCV}$. For PWID who are not routinely engaged in medical care, NSEP may also be utilized resource for HCV screening.

Guided by Gelberg-Andersen model [24], we categorized multi-level factors that may facilitate or hinder HCV testing behavior of PWIDs. Contrary to our hypothesis, we found that most predisposing factors were associated with higher odds of utilisation of $\mathrm{HCV}$ testing as compared to enabling and need factors. This indicates that access to comprehensive services by PWID relates to socio-demographic factors. In the final adjustment model, education, marital status, place of residence and duration of injecting drug use were found to significant enable uptake of HCV testing services while alcohol use, mobility and unprotected sex were found to significantly inhibit uptake to $\mathrm{HCV}$ testing services. This indicates that targeting and reaching PWID who may be in need of HCV testing is complex, and cannot be determined by one element of vulnerability. This finding, coupled with the finding about variation in $\mathrm{HCV}$ risk factors across different age groups and settings, raises concern about an important dimension of the response to $\mathrm{HCV}$ in large heterogeneous countries such as India. National policies in India are translated into strategies and action plans at the state level. In order to develop an effective overall response, it is important to know which factors should be the highest-priority targets for interventions at the state and local levels. Multiple domains of information, including epidemiology as well as knowledge of program, geographic, and community settings, may be essential to develop effective interventions.

This study has several limitations. First, this sample was drawn from a group of organizations involved in implementing a specific National AIDS Control Program activity, and results cannot be assumed to represent PWID who are not receiving the same services. Second, study participants were recruited from the client rosters of the needle and syringe exchange facilities, and the dearth of female clients is reflected in the all-male composition of the study cohort. Study results thus do not reflect the experience of an important but often hidden segment of India's injection drug-using population. Results are further limited by fact that study participants were from two districts in different Indian states. Whether findings can be generalized to PWID in other parts of those states or other parts of the country remains to be determined. Additionally, we could not verify the accuracy of self-reported data on HCV testing. Some study participants may have answered this question incorrectly due to recall bias, social desirability bias or some other reason. The data that were collected provided little insight into system-level factors that may affect $\mathrm{HCV}$ testing uptake, such as funding, regulation and service delivery infrastructure. Despite these limitations, the study findings may inform comprehensive interventions for systems delivering care to specific high-risk groups. Our findings are important because they suggest identifiable characteristics that can be targeted to reduce the risk and spread of $\mathrm{HCV}$ infection.

\section{Conclusion}

Our findings highlight important factors that may be useful to increase HCV testing rates among PWID, which may strengthen prevention and reduce transmission of the infection. This study concludes that predisposing and enabling determinants provide an area for developing effective interventions to improve $\mathrm{HCV}$ testing practices and risk reduction. Prevention programs that address safe injecting and sexual practices, adherence to OST and frequent mobility customized for PWID by 'age' is strongly recommended to prioritize $\mathrm{HCV}$ risk reduction strategies. The priority factors found in this study coincide with the HIV prevention program in the country; hence integration of $\mathrm{HCV}$ within the harm reduction program could be a possible solution to address the HCV burden among PWID.

\section{Abbreviations \\ BPL, Below Poverty Line; HCV, Hepatitis C Virus; HIV, Human \\ Immunodeficiency Virus; NGO, Non-government Organization; NSEP, Needle Syringe Exchange Program; OST, Opioid Substitution Therapy; PWID, People who Inject Drugs; STI, Sexually Transmitted Infection; TI, Targeted Intervention}

\section{Acknowledgements}

The authors would like to acknowledge the Bristol-Myers Squibb Foundation, which provided funding for the intervention. We acknowledge the guidance and support provided by state government authorities. Thanks are also extended to all healthcare providers of Manipur and Punjab states, particularly Imphal and Amritsar districts. The authors thank our implementation partners, the Manipur Network of Positive People and Abhivyakti Foundation, Punjab. The study would have not been possible without the active participation of people who inject drugs in Amritsar and Imphal districts.

\section{Funding}

This work was a part of the project funded by the Bristol-Myers Squibb Foundation (grant \#1410).

Availability of data and materials

The raw data and materials may not be shared due to our agreement with the government authorities and community organization facilities.

Authors' contributions

RS conceptualized, defined the research theme and drafted the manuscript. $\mathrm{PB}, \mathrm{AW}$ and RG performed the data collection and management. RS and PB performed the statistical analyses and interpreted the data. All authors read 
and critically revised the subsequent drafts of the manuscript. All authors approved the final manuscript.

\section{Authors' information}

All authors belong to MAMTA Health Institute for Mother and Child, New Delhi, India.

\section{Competing interest}

All authors declared no financial and non-financial competing interests.

\section{Consent for publication}

Not applicable.

\section{Ethics approval and consent to participate}

Prior to the interviews, participants were informed about the purpose of the study and were told they could decline to participate or withdraw at any time. Oral informed consent was obtained before each interview began. In addition, consent was obtained from the caregivers of participants aged 15-19. To protect confidentiality, potential personal identifiers were deleted from the database. The Technical Review Committee of MAMTA Health Institute for Mother and Child approved the study in the year 2015, as did the local government and the head of the community organization facilities of the State AIDS Control Program.

Received: 17 March 2016 Accepted: 20 June 2016

Published online: 29 June 2016

\section{References}

1. World Health Organization. Hepatitis C: fact sheet no. 164. Available from: http://www.who.int/mediacentre/factsheets/fs164/en/. Accessed 10 Aug 2015

2. Caccamo G, Saffioti F, Raimondo G. Hepatitis B virus and hepatitis C virus dual infection. World J Gastroenterol. 2014;20(40):14559-67. doi:10.3748/wjg. v20.140.14559. PMCID:PMC4209523.

3. World Health Organization Executive Board (2009). Viral hepatitis. Report by the Secretariat. EB126/15, 12 November, 2009. Available from: http://apps. who.int/gb/ebwha/pdf_files/EB126/B126_15-en.pdf. Accessed 10 Aug 2015.

4. World Health Organization. Prevention and control of viral hepatitis infection. Framework for global action. Available from: http://www.who.int/ csr/disease/hepatitis/GHP_Framework_En.pdf. Accessed 12 July 2015.

5. Perz JF, Armstrong GL, Farrington LA, Hutin YJ, Bell BP. The contributions of hepatitis $B$ virus and hepatitis $C$ virus infections to cirrhosis and primary liver cancer worldwide. J Hepatol. 2006;45:529-38.

6. Aceijas C, Rhodes T. Global estimates of prevalence of HCV infection among injecting drug users. Int J Drug Policy. 2007;18:352-58.

7. Solomon SS, Mehta SH, Srikrishnan AK, Solomon S, McFall AM, Laeyendecke $\mathrm{O}$, et al. Burden of hepatitis C virus disease and access to hepatitis C virus services in people who inject drugs in India: a cross-sectional study. The Lancet. 2015;15:36-45.

8. Panda S, Roy T, Pahari S, Mehraa J, Sharma N, Singh G, et al. Alarming epidemics of human immunodeficiency virus and hepatitis $C$ virus among injection drug users in the northwestern bordering state of Punjab, India: prevalence and correlates. Int J STD AIDS 2013;12:2-11. http://std.sagepub. com/content/early/2013/12/16/0956462413515659. Accessed 22 June 2016.

9. Basu D. Overview of substance abuse and hepatitis $C$ virus infection and co-infections in India. J Neuroimmune Pharmacol. 2010;5:496-506.

10. Basu D et al. Hepatitis C virus (HCV) infection \& risk factors for HCV positivity in injecting \& non-injecting drug users attending a de-addiction centre in northern India. Indian Journal of Medical Research. 2015;142:311-6.

11. Government of India. Quarterly Newsletter of the National Center for Disease Control. January to March 2014;Vol 3: Issue 1. p. 7. http://ncdc.gov. in/writereaddata/linkimages/NewsLtr0103_20146480274026.pdf.

12. Sulkowski MS, Gardiner DF, Rodriguez-Torres M, the Al444040 Study Group, et al. Daclatasvir plus sofosbuvir for previously treated or untreated chronic HCV infection. N Engl J Med. 2014;370:211-21.

13. Afdhal N, Zeuzem S, Kwo P, the ION-1 Investigators, et al. Ledipasvir and sofosbuvir for untreated HCV genotype 1 infection. N Engl J Med. 2014;370: 1889-98.

14. World Health Organisation, Hepatitis C treatment Guidelines, http://www. who.int/mediacentre/news/releases/2014/hepatitis-guidelines/en/. Accessed 12 Aug 2015.
15. World Health Organization. Key global facts and figures in 2011, Fact Sheet no 279. 2011

16. Davis KL, Mitra D, Medjedovic J, Beam C, Rustgi V. Direct economic burden of chronic hepatitis $C$ virus in a United States managed care population. J Clin Gastroenterol. 2011;45(2):e17-24.

17. Islam MM, Topp L, Day CA, Dawson A, Conigrave KM. The accessibility, acceptability, health impact and cost implications of primary healthcare outlets that target injecting drug users: a narrative synthesis of literature. Int J Drug Policy. 2012;23(2):94-102.

18. Joanna Buffington and T. Stephen Jones, M. Integrating Viral Hepatitis Prevention into Public Health Programs Serving People at High Risk for Infection: Good Public Health. Public Health Reports. 2007;Suppl 2:122. http://www.publichealth reports.org/issueopen.ffm?articlelD=1852. Accessed 12 Nov 2015.

19. WHO. Guidance on Prevention of viral hepatitis $B$ and $C$ among people who inject drugs, 2012. http://apps.who.int/iris/bitstream/10665/75357/1/ 9789241504041_eng.pdf. Accessed 27 Oct 2015.

20. Bristol-Myers Squibb Foundation, USA. http://www.bms.com/foundation/ Pages/home.aspx. Accessed 27 Apr 2015.

21. MAMTA Health Institute for Mother and Child, India. www.mamta-himc.org Accessed 27 Apr 2015

22. United Nations Office on Drugs and Crime, Government of India Ministry of Social Justice and Empowerment. Injecting drug use and HIV in India: an emerging concern. 2004. www.unodc.org/pdf/india/publications/idu_and_ HIVAIDS_in_India-Monograph/08_extentofiduhiv-aidsinindia.pdf. Accessed 12 Oct 2015.

23. Government of Punjab. Human Development Report. 2004.

24. Gelberg L, Andersen RM, Leake BD. The Behavioral Model for Vulnerable Populations: application to medical care use and outcomes for homeless people. Health Service Research. 2000;34(6):1273-302.

25. Lewis JH, Andersen RM, Gelberg L. Health care for homeless women: unmet needs and barriers to care J Gen Intern Med. 2003:18(11):921-8.

26. Stein JA, Andersen RM, Koegel P, Gelberg L. Predicting health services utilization among homeless adults: a prospective analysis. J Health Care Poor Underserved. 2000;11(2):212-30.

27. Stein JA, Andersen RM, Robertson M, Gelberg L. Impact of hepatitis B and C infection on health services utilization in homeless adults: a test of the Gelberg-Andersen Behavioral Model for Vulnerable Populations. Health Psychol. 2012;31(1):20-30.

28. Desai MM, Rosenheck RA. HIV testing and receipt of test results among homeless persons with serious mental illness. Am J Psychiatry. 2004;161(12): 2287-94.

29. Government of India, Ministry of Health and Family Welfare. Targeted Intervention of National AIDS Control Program Phase IV (2012-17). http:// www.naco.gov.in/upload/NACP\%20-\%20IV/NACP-IV\%20Strategy\%20 Document\%20.pdf. Accessed 22 June 2016

30. Planning Commission, Government of India. Report of the expert group to review the methodology for measurement of poverty. June 2014. http:// planningcommission.nic.in/reports/genrep/pov_rep0707.pdf Accessed 12 Nov 2015

31. Government of India, Ministry of Health and Family Welfare. Targeted Intervention of National AIDS Control Program Phase IV (2012-17). HRG Registration Form. https://www.google.co.in/url?sa=t\&rct=j\&q= \&esrc $=s \&$ source $=$ web\&cd $=5 \&$ cad $=r j a \& u a c t=8 \&$ ved $=0$ ahUKEwjH6P_R_ aDKAhULFCwKHc6FCTQQFggsMAQ\&url=http\%3A\%2F\%2Fnaco.gov. in\%2Fupload\%2FNGO\%2520\%26\%2520Targeted\%2FMonitoring\% 2FData\%2520Collection\%2520Tools\%2FTools\%2520used\%2520by\% 25200RW\%2FHRG registration form.doc\&usg=AFQjCNHChoGkkyPeP7A ODGd4SCmnx5bYoQ\&sig2=xd56ZMjxfPx9mrhMM3o_5w\&bvm=bv 111396085,d.bGg. Accessed 12 Nov 2015.

32. Strathdee SA, Stockman JK. Epidemiology of HIV among injecting and non-injecting drug users: current trends and implications for interventions. Curr HIV/AIDS Rep. 2010;7(2):99-106.

33. Jemima A. Frimpong, Erick G. Guerrero, Yinfei Kong and Gary Tsai. Correlates of HIV testing and receipt of test results in addiction health services in Los Angeles County. Substance Abuse Treatment, Prevention, and Policy 2015; doi:10.1186/s13011-015-0026-1.

34. The UFO Model: An HCV prevention intervention for young adult IDU. http://www.ufomodel.com. Accessed 2 May 2016. 